\section{Nyrebok for svenske pasienter}

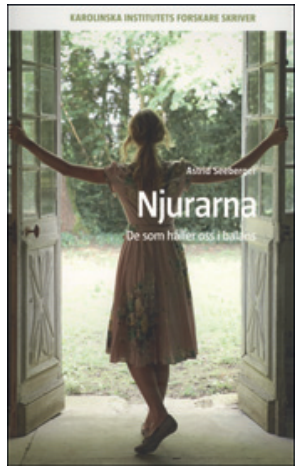

\section{Astrid Seeberger}

Njurarana

De som håller oss i balans. 168 s, tab, ill. Stockholm: Karolinska Institutet University Press 2011. Pris SEK 198 ISBN 978-91-85565-28-3

Dette er en bok for pasienter, pårørende og - med samhandlingsreformen i tankene - også for helsepersonell i førstelinjetjenesten. I utgangspunktet ville dette vært en egnet bok ved nyrekursene som de fleste sykehus tilbyr pasienter med kronisk nyresykdom. Det er viktig at pasientene får kunnskap om egen sykdom for å få forståelse og kjennskap til utredning og behandling.

Kapitlene handler om anatomi, nyrenes oppgaver og hva som skjer når nyrene svikter. Videre diskuterer forfatteren behandling, med søkelyset særlig rettet mot dialyse og nyretransplantasjon. Det er rikholdig med fine illustrasjoner i de 13 kapitlene.

Forfatteren skal ha all ære for at hun skriver en slik bok for pasientene. Dette er en bok som definitivt ville ha egnet seg også for norske pasienter med nyresykdom, men det er åpenbart en del hindringer og forskjellige tradisjoner som gjør at den ikke uten videre kan anbefales for norske pasienter.

Hver tredje eldre over 70 år i Norge har tegn til kronisk nyresykdom, ifølge Helseundersøkelsen i Nord-Trøndelag (HUNT), og i den voksne befolkningen er det noe over $10 \%$. Antall dialysepasienter er lavt i Norge i forhold til i Sverige siden en større andel av pasientene med mest alvorlig nyresvikt blir transplantert.

Boken er skrevet på svensk og for svenske forhold. Det er en åpenbar ulempe. Det hele avsluttes med den glimrende forskningen som er gjort, og som gjøres i Sverige, og angis som «värdsledande». Det er den absolutt, men boken ville ha tjent på å være litt mer åpen overfor andre forskningsmiljøer. Store norske epidemiologiske undersøkelser fra Nord-Trøndelag og Tromsø har vakt internasjonal oppsikt, og det virker merkelig at undersøkelser i USA med en helt annen befolkning enn den svenske blir omtalt når de skal angi hvor mange kronisk nyresyke det er i Sverige.

Den hyppigste årsaken til nyresykdom som krever dialyse/transplantasjon, er i de fleste vestlige land nefrosklerose og diabetisk nyresykdom, ofte kombinert. Nefrosklerose er beskrevet med 5-6 linjer, diabetisk nyresykdom mer grundig.

Ordet hypertensjon finnes ikke i stikkordregisteret, til tross for at blodtrykksforhøyelse er viktig som årsak til nyresykdom, men også desidert den viktigste faktoren som man kan påvirke for å hindre progrediering av nyresykdom. Rett nok nevnes blodtrykk (både lavt og høyt) sporadisk i teksten. Mange nyrepasienter karakteriseres av å ha volumavhengig hypertensjon, og da betyr saltinntak mye. Dette er ytterst stemoderlig behandlet, til dels litt uklart.

Min konklusjon er at til tross for at dette er en viktig bok, bør den tilpasses norske forhold for å kunne bli anbefalt brukt for norske pasienter.

\section{Omsorg ved livets slutt}

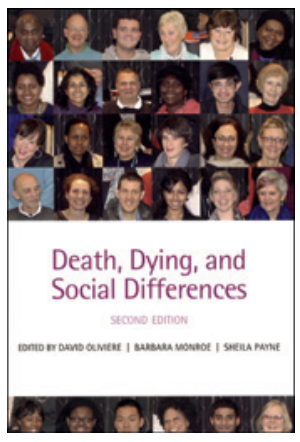

\author{
David Oliviere, Barbara Munroe,
}

Sheilla Payne, red.

Death, dying, and social differences

2. utg. 226 s, ill. Oxford: Oxford University

Press, 2011. Pris GBP 35

ISBN 978-0-19-959929-5

Omsorgen for døende utenom de etablerte hospicene er temaet for denne boken. Budskapet er viktig: Mange andre sosiale grupper burde få en liknende omsorg som pasienter på hospice får ved livets slutt. Den er skrevet av folk som er knyttet til hospicene, og de har mye å fare med.

I den første delen forklarer forfatterne formålet generelt og grundig. De fremhever at hospicepasientene stort sett har langtkommen kreft, der forløpet er forholdsvis kjent og kortvarig. Denne delen blir altfor ordrik.

Den andre delen er derimot langt fra selvfølgelig. Her kommer en mengde vurderinger og noen erfaringer med slikt arbeid blant en rekke sosiale grupper. Disse pasientene er mye «vanskeligere» enn de typiske hospicepasientene, de har gjerne et mer langtrukkent siste stadium med ulike symptomer. Dette gjelder den langt største gruppen, nemlig de vanlige sykehjemspasientene. De er tatt hånd om av institusjoner, dessverre med få faglige og menneskelige ressurser sammenliknet med hospicene. I England er hospicene nå private. Spørsmålet er om personalet på sykehjemmene kan lære noe av hospicene, selv med små ressurser.

Motsatt står de alvorlig syke narkomane som har vekslende og uberegnelige forløp og dertil ofte har svært individuelle behov, både medisinsk og sosialt. De dør ofte under forhold som opprører alle, men av og til på sykehus. Ingen forsøk med hospice for disse er kjent, bare enkeltkasus, men forfatterne gir noen gode råd.

Andre viktige grupper er psykisk syke, psykisk utviklingshemmede, demente, fanger, flyktninger, hjemløse og romfolket - ulike grupper som alle får egne kapitler. Ungdom kan også ha særegne behov, noe forfatterne diskuterer. De har sikkert rett $i$ at mange i disse gruppene burde tilbys en bedre omsorg ved livets slutt enn de stort sett får i dag.

Romfolket har interessante særtrekk i sin kultur i forhold til døden. De dør på sykehus fordi de ikke kan besmitte hjemmet ved å dø der. De vekker gjerne oppsikt på sykehuset fordi alle slektninger og venner skal ta avskjed, gjerne 150 mennesker og ofte med omfattende ritualer. Noen sykehus i England har egne rom for dette.

Alle som jobber med omsorg for disse gruppene, har noe å lære av denne boken. Jeg anbefaler den derfor for alle som er interessert i omsorg ved livets slutt. Ledelsen ved alle sykehjem bør antakelig diskutere temaet, om de da ikke nylig har gjort det.

\section{Bjørgulf Claussen}

Institutt for helse og samfunn

Universitetet i Oslo 